\title{
Expression Patterns of Ki-67, Cyclin A, and Cyclin D1 during Tooth Development
}

\author{
Hyuk-Jae Kwon $^{\dagger}$, Kyung-Sik Yoon, Han-Sung Jung ${ }^{\dagger}$ \\ Division in Anatomy and Developmental Biology, Department of Oral Biology, Research Center for Orofacial Hard Tissue \\ Regeneration, Brain Korean 21 project, Oral Science Research Center, College of Dentistry, Yonsei University
}

(Received 24 January 2013, revised 20 March 2013, accepted 22 March 2013, Published Online 30 March 2013)

\begin{abstract}
Dental epithelial and mesenchymal cells that form the teeth undergo dynamic changes in cell cycle during tooth development and morphogenesis. Although proliferation has been known as a key event during odontogenesis, the cell cycle phases and their relations with the complicated molecular mechanisms of tooth development are not fully understood yet. This study comparatively examined the expression patterns of Ki-67, cyclin A, and cyclin D1 during tooth development in the mouse incisor and molar in order to identify the cellcycle characteristics during odontogenesis. We found that Ki-67 and cyclin A were expressed in the proliferating cells in the dental epithelial and mesenchymal tissues at the bud, cap and bell stages. Cycln D1 showed distinct expression in the incisor odontoblast region and the enamel knot, in which Ki-67 nor cyclin A was expressed. Our results provide specific information on the cell cycle phases during tooth development that may provide clues to relate them with the complex odontogenic mechanisms. Furthermore, we suggest that our findings enlightened the previous studies on the incisor odontoblasts and the enamel knot during tooth development.
\end{abstract}

Keywords : Cell cycle, Ki-67, Cyclin A, Cyclin D1, Tooth development

\section{Introduction}

Tooth development during the embryonic stages involves dynamic changes in shape and size of the tooth germ as it proceeds through the bud, cap, and bell stages [1]. These morphological characters of the tooth germ result from the morphogenesis of the dental epithelium of the tooth germ, and their changes are due to the epithelial-mesenchymal interactions mediated via various genes and signaling mol-

This study was supported by a grant of the Korean Health Technology R\&D Project, Ministry of Health \& Welfare, Republic of Korea (A110638). This research was supported by Basic Science Research Program through the National Research Foundation of Korea (NRF) funded by the Ministry of Education, Science and Technology (2012R1A1A2009400).

The author $(\mathrm{s})$ agree to abide by the good publication practice guideline for medical journals.

The author(s) declare that there are no conflicts of interest.

${ }^{\dagger}$ These authors contributed equally to this work.

Correspondence to : Hyuk-Jae Kwon, Han-Sung Jung (Division in Anatomy and Developmental Biology, Department of Oral Biology, College of Dentistry, Yonsei University)

E-mail : eddy8139@yuhs.ac, hsjung@yuhs.ac ecules [2,3]. The enamel knot is an important signaling center in the dental epithelium at the cap stage that secretes these growth stimulatory molecules, while its cells themselves do not proliferate $[4,5]$. In response to these signals, dramatic changes in cell cycle occur throughout the tooth germ, which is precisely controlled in space and time, in order to enable the cells to go under proliferation [6].

The cell cycle can be divided into two periods: interphase and mitosis (M) phase. The interphase can be subdivided into three distinct phases: G1 phase, S phase, and G2 phase; the $M$ phase can be subdivided into two distinct phases: chromosome-dividing mitosis and cytoplasm-dividing cytokinesis [7]. G0 phase is known as a quiescent phase, in which the cells temporarily or reversibly stop dividing. The cell cycle is progressed via two classes of molecules, cyclins and cyclin-dependent kinases (CDKs), which bind to form heterodimer complexes [8]. Cells constitutively express CDKs and cyclins at specific phases in response to various molecular signals [9]. Cyclin D is the first cyclin expressed in the cell cycle, which forms a com- 
plex with the CDK in order to regulate transition from G1 to $S$ phase [10]. This in turn leads to the expression of cyclin E, cyclin A, DNA polymerase, thymidine kinase, etc. Cyclin A is also essential in cell cycle progression, which regulates multiple cell cycle steps: $\mathrm{G} 1$ to $\mathrm{S}$ phase transition and $\mathrm{G} 2$ to $\mathrm{M}$ phase transition, depending on which CDK it associates with [11,12]. Antigen Ki-67 is a cell proliferation marker that is present in cells in G1, S, $\mathrm{G} 2$, and mitosis phases, but is absent in the $\mathrm{G} 0$ phase [13]. It is known that during the G0 phase, cyclins, CDKs, and Ki-67 disappear along with cell cycle arrest. However, there was a study reporting that cyclin D1 is expressed in the G0 phase [14].

In this study, we comparatively examined the expression patterns of Ki-67, cyclin A, and cyclin D1 during mouse tooth development in order to identify the cell-cycle characteristics of various cell groups composing the tooth germ. We found that $\mathrm{Ki}-67$, cyclin A, and cyclin D1 were expressed in the proliferating cells in the dental epithelial and mesenchymal tissues. We also identified here that a distinct region of cells were present in the incisor odontoblasts and the enamel knot region that were Ki-67-negative, cyclin A-negative, and cyclin D1-positive. Thus, our study provides important cell cycle information on the cells in the developing tooth germ and enlightens our knowledge about the nature of the incisor odontoblasts and the enamel knot in tooth development.

\section{Materials and Methods}

All experiments were performed according to the guidelines of the Intramural Animal Use and Care Committee of the College of Dentistry, Yonsei University.

\section{Animals}

Adult ICR mice were housed in a temperature-controlled room $\left(22^{\circ} \mathrm{C}\right)$ under artificial illumination conditions (lights on from 5:00 to 17:00) and 55\% relative humidity, with access to food and water ad libitum. The embryos were obtained from time-mated pregnant mice. E0 was designated as the day on which the presence of a vaginal plug was confirmed. Embryos at each developmental stage (E13, E14, and E16) were used in this study.

\section{Immunohistochemistry}

Embryos were fixed in $4 \%$ paraformaldehyde, embedded in wax, and sectioned at $4 \mu \mathrm{m}$. Sections were blocked against endogenous peroxidase in $0.3 \%$ hydrogen peroxide for $15 \mathrm{~min}$. The sections were boiled in $10 \mathrm{mM}$ citrate buffer ( $\mathrm{pH}$ 6.0) for $15 \mathrm{~min}$ and then cooled at room temperature for $20 \mathrm{~min}$. Sections were blocked with normal goat serum for $30 \mathrm{~min}$ to reduce nonspecific antibody interactions. Slides were incubated in rabbit anti-Ki-67 (Novus Biologicals, CO, USA, $1: 200$ ), rabbit anti-cyclin A (Santa Cruz Biotechnology, CA, USA, $1: 200$ ), or mouse anti-cyclin D1 (Santa Cruz Biotechnology, CA, USA, 1 : 200) overnight at $4^{\circ} \mathrm{C}$. After washing with PBS, the secondary antibody [biotinylated goat anti-rabbit (Life Technologies, CA, USA) or anti-mouse (Agilent Technologies, CA, USA)] was added and incubated for $15 \mathrm{~min}$, followed by streptavidin peroxidase for another $15 \mathrm{~min}$ at room temperature. Samples were visualized using a diaminobenzidine reagent kit (Life Technologies, CA, USA) and counterstained with hematoxylin. For immunofluorescence staining, goat anti-rabbit IgG FITC (Santa Cruz Biotechnology, CA, USA) was used for Ki-67; alexa fluor 555 (Life Technologies, CA, USA) was used for cyclin D1, respectively, as secondary antibodies.

\section{Results}

\section{Cell cycle changes during molar tooth development}

In order to analyze the cell cycle changes during the molar tooth development, the expression patterns of Ki-67, cyclin A, and cyclin D1 proteins were examined in the mouse molar tooth germ between embryonic day (E) 13 to E16 (Figs. 1 and 4). At the bud stage (E13), Ki-67, which detected cells that were undergoing cell proliferation, was localized broadly in the tooth germ, which is composed of the dental epithelium and dental mesenchyme. Particularly, $\mathrm{Ki}-67$ was detected densely in the basal cell layer of the dental epithelium and sparsely in the dental mesenchyme surrounding the bud-shaped dental epithelium (Fig. 1A, D). Cyclin A was detected in regions similar to Ki-67, but the density of the cells expressing cyclin A was lower than that of Ki-67 (Fig. 1G). Cyclin D1 was also detected in regions similar to $\mathrm{Ki}-67$ and cyclin $\mathrm{A}$, but the density of 

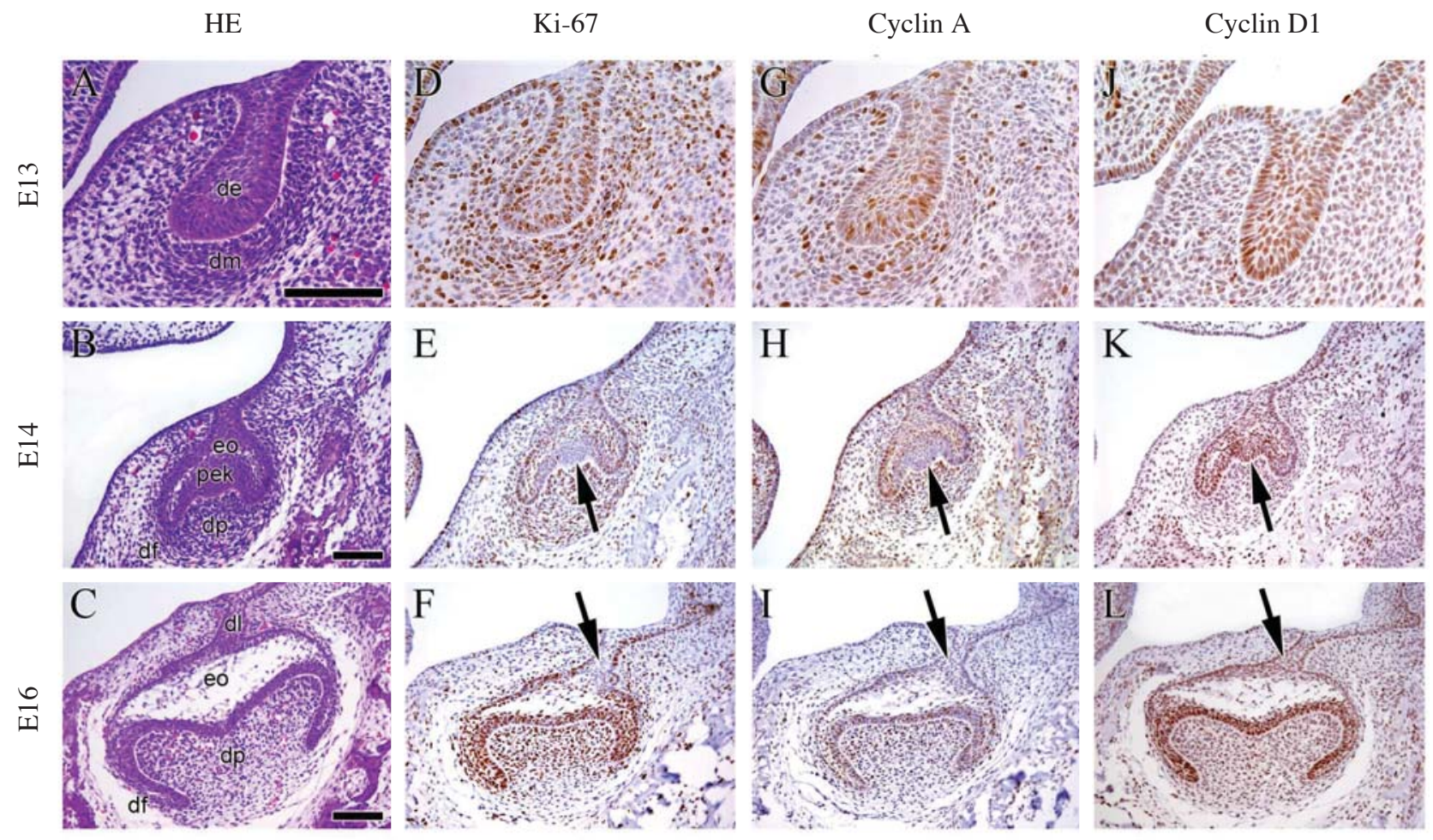

Fig. 1. Localization of Ki-67, cyclin A, and cyclin D1 proteins during mouse molar tooth development. All samples are frontal sections from E13 to E16. (A C ) H-E staining of the molar tooth germ at the bud stage (A), cap stage (B), and bell stage (C). (D) At E13, Ki-67 is localized in the dental epithelium and dental mesenchyme of the tooth germs. (E) At E14, Ki-67 is present in the enamel organ, dental papilla, and dental follicle, but it is absent in the primary enamel knot (arrow). (F) At E16, Ki-67 continues to be present throughout the tooth germ except the non-basal cell layer in the dental lamina (arrow). (G) At E13, cyclin A is localized in the dental epithelium and dental mesenchyme; less cells are detected compared to Ki-67. (H) At E14, cyclin A is present in the enamel organ, dental papilla, and dental follicle, but it is absent in the primary enamel knot (arrow). (I) At E16, cyclin A continues to be present in the tooth germ except the nonbasal cell layer in the dental lamina (arrow). (J) At E13, cyclin D1 is localized in the dental epithelium and dental mesenchyme; intensity is stronger in the dental epithelium compared to the dental mesenchyme. (K) At E14, cyclin A is present in the enamel organ, dental papilla, and dental follicle; it is also present in the primary enamel knot (arrow). (L) At E16, cyclin D1 continues to be present in the tooth germ and even in the dental lamina (arrow) at the bell stage. de, dental epithelium; df, dental follicle; dl, dental lamina; dm, dental mesenchyme; dp, dental papilla; eo, enamel organ; pek, primary enamel knot. Scale bars, $100 \mu \mathrm{m}$.

the positively stained cells were lower than Ki-67 but higher than cyclin A (Fig. 1J). Interestingly, strong detections of Ki-67 and cyclin A, respectively, were present in both in the dental epithelium and mesenchyme, whereas that of cyclin D1 was observed mostly in the dental epithelium. At the cap stage (E14), the tooth germ was composed of the cap-shaped epithelial enamel organ, mesenchymal dental papilla, and mesenchymal dental follicle (Fig. 1B). Ki67 marked proliferating cells in the tooth germ except the primary enamel knot region (Fig. 1B, E). Cyclin A showed expression patterns similar to that of Ki-67, especially the absence of localization in the primary enamel knot region (Fig. 1H). On the other hand, cyclin D1 was strongly localized in the majority of the cells composing the dental epi- thelium and even in the primary enamel knot region; the dental mesenchymal cells exhibited a relatively weaker localization than the dental epithelial cells (Fig. 1K). At the bell stage (E16), proliferating cells expressing $\mathrm{Ki}-67$ were found in the bell-shaped enamel organ, dental papilla, and dental follicle regions (Fig. 1C, F). A group of cells were Ki-67-negative in the non-basal cell layer of the dental lamina, which lied between the dental epithelium and the oral epithelium (Fig. 1F, arrow). Cyclin A showed weaker detection and lower positive cell density, but it was localized in the regions similar to that of Ki-67, especially showing absence in the dental lamina region (Fig. 1I). The localization regions of cyclin D1 included that of Ki-67 and cyclin A, but cyclin D1 was even present in the dental 

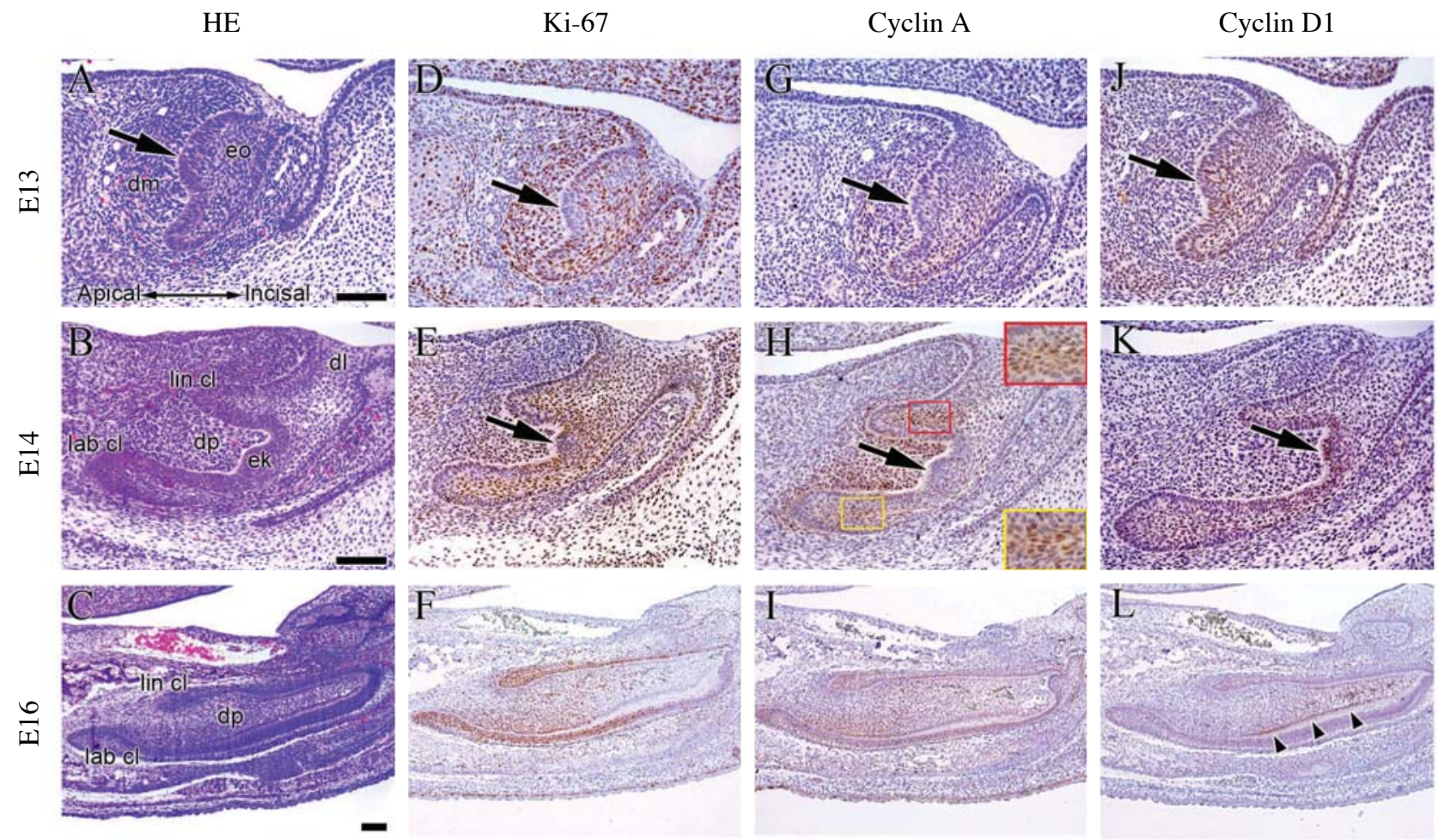

Fig. 2. Localization of Ki-67, cyclin A, and cyclin D1 proteins during mouse incisor tooth development. All samples are sagittal sections from E13 to E16. (A C ) H-E staining of the incisor tooth germ at the bud stage (A), cap stage (B), and bell stage (C). (D) At E13, Ki-67 is localized in the enamel organ and dental mesenchyme except the cells in the bulbous protrusion (arrow). (E) At E14, Ki-67 is densely localized in the dental papilla and the enamel organ except the enamel knot region (arrow). (F) At E16, Ki-67 is localized in the dental epithelium and dental mesenchyme in the apical part of the incisor tooth germ. (G) At E13, cyclin A is localized in the enamel organ and dental mesenchyme except the cells in the bulbous protrusion (arrow); less cells are detected compared to Ki-67. (H) At E14, cyclin A is densely localized in the dental papilla and the stellate reticulum layer cells in the lingual and labial cervical loops. However, cyclin A was absent in the enamel knot (arrow). (I) At E16, cyclin A is localized in the dental epithelium and dental mesenchyme in the apical part of the incisor tooth germ; expression is weaker compared to Ki-67. (J) At E13, cyclin D1 is localized in the enamel organ and dental mesenchyme, including the cells in the bulbous protrusion (arrow). (K) At E14, cyclin D1 is localized in the dental papilla and the enamel organ, including the enamel knot (arrow). (L) E16, cyclin D1 is specifically localized in the odontoblasts and mesenchymal cells nearby them in the middle and incisal parts of the dental papilla (arrowheads). dl, dental lamina; dm, dental mesenchyme; dp, dental papilla; ek, enamel knot; eo, enamel organ; lab cl, labial cervical loop; lin cl, lingual cervical loop. Scale bars, $100 \mu \mathrm{m}$.

lamina region (Fig. 1L).

\section{Cell cycle changes during incisor tooth development}

The developmental mechanisms of the molar and incisor are known to have similarities and differences. One of the differences in the mouse teeth is that the incisor grows continuously due to the persisting tooth formation in the apical region and tooth matrix-removal in the incisal region of the incisor [15]. Therefore, the cell cycle changes were studied during incisor tooth development by analyzing the expression patterns of Ki-67, cyclin A, and cyclin
D1 proteins in the mouse incisor tooth germ at the bud stage (E13), cap stage (E14), and bell stage (E16) (Figs. 2, 3 , and 5). At the bud stage, Ki-67 was strongly detected in the enamel organ and the condensed dental mesenchyme (Fig. 2A, D). However, a group of cells located in the bulbous protrusion of the enamel organ were Ki-67-negative (Fig. 2D, arrow). Cyclin A exhibited expression patterns similar to that of $\mathrm{Ki}-67$, but the number of positively detected cells were less than that $\mathrm{Ki}-67$; prominently strong detection was found in the stellate reticulum cells in the dental epithelium (Fig. 2G). Cyclin A was also absent in the bulbous protrusion (Fig. 2G, arrow). Cyclin D1 was detected in the dental epithelium and mesenchyme, but 
more cells showed positive localization compared to cyclin A (Fig. 2J). Different from Ki-67 and cyclin A, greater number of cells showed strong localization of cyclin D1 in the dental epithelium compared to the dental mesenchyme, and its localization was present even in the bulbous epithelial protrusion (Fig. 2J, arrow). At the cap stage, Ki-67 was strongly localized in the majority of the dental papilla cells and the enamel organ (Fig. 2B, E). However, it was weak in the enamel knot region (Fig. 2E, arrow). Strong detection of cyclin A in the dental mesenchyme was similar to that of $\mathrm{Ki}-67$, but in the dental epithelium, it was detected mostly in the stellate reticulum in the labial and lingual cervical loops but not in the enamel knot (Fig. 2H). Cyclin D1 was expressed in the dental epithelium and mesenchy- me; the expression was stronger in the dental epithelium, including the enamel knot region, compared to the dental mesenchyme (Fig. 2K). At the bell stage, proliferating cells expressing $\mathrm{Ki}-67$ were found mostly in the dental epithelium except the incisal tip, and in the dental mesenchymal cells near the Ki-67-expressing dental epithelium (Fig. 2C, F). Cyclin A showed weaker signals, and its expression pattern was similar to that of Ki-67 (Fig. 2I). On the other hand, strong signals of cyclin D1 were found in the middle and incisal regions of the incisor tooth germ. Particularly, cyclin D1 was localized strongly in the odontoblasts and the dental papilla cells near these cyclin D1-positive odontoblasts (Fig. 2L, arrowheads). Cyclin D1 was weakly expressed in other parts of the dental epithelium (Fig. 2L).
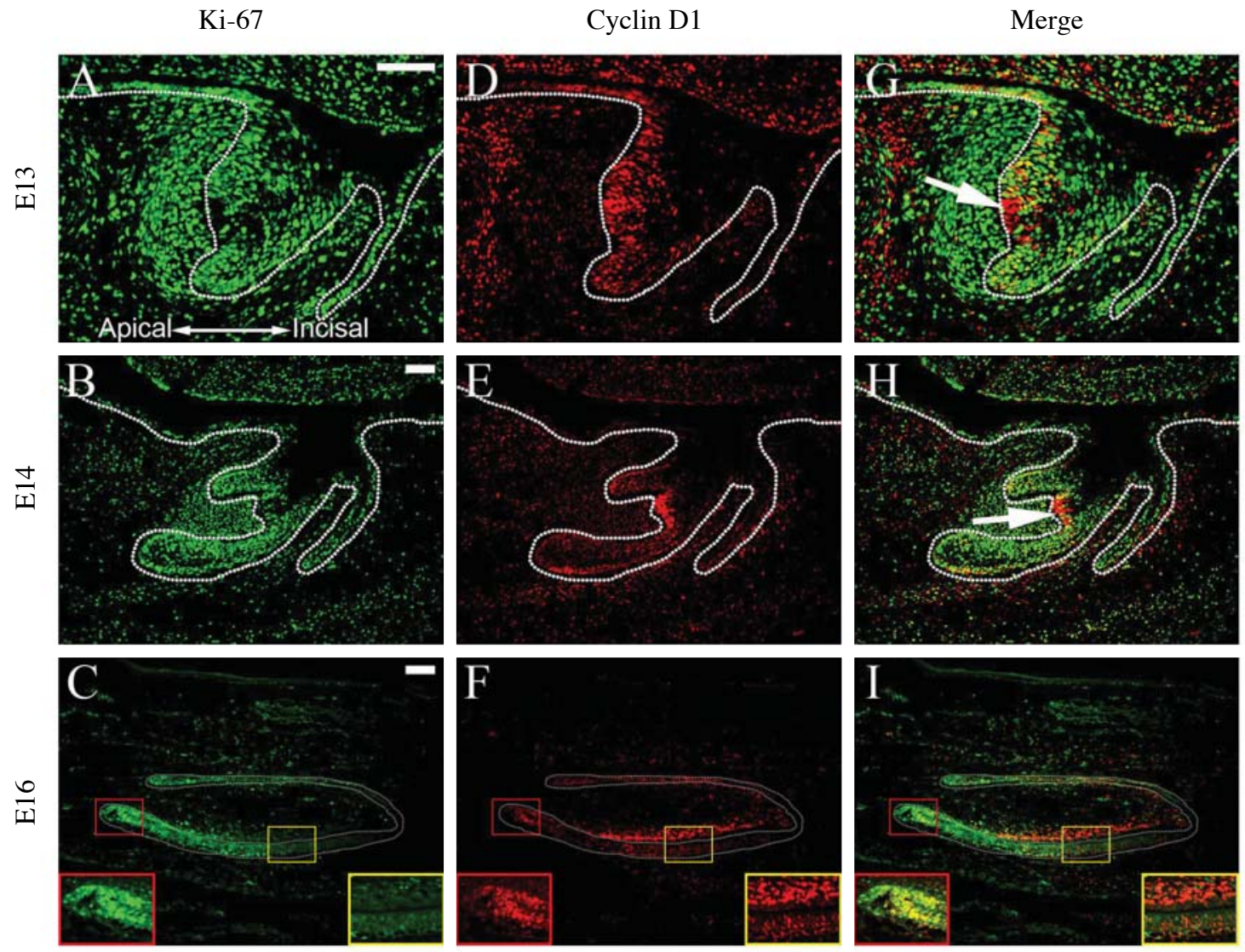

Fig. 3. Co-localization of Ki-67 and cyclin D1 proteins during mouse incisor tooth development. All samples are sagittal sections at the bud stage (E13), cap stage (E14), and bell stage (E16). (A C) Ki-67 detection. (D F) Cyclin D1 detection. (G I) Co-localization of Ki67 and cyclin D1. (A, D, G) At E13, epithelial cells in the bulbous protrusion in the enamel organ are Ki-67-negative and cyclin D1positive (arrow). (B, E, H) At E14, epithelial cells in the enamel knot are Ki-67-negative and cyclin D1-positive (arrow). (C, F, I) At E16, Ki-67 and cyclin D1 are co-localized in the epithelial cells within the labial cervical loop region (red boxes); odontoblasts and adjacent mesenchymal cells in the labial part of the dental papilla are Ki-67-negative and cyclin D1-positive (yellow boxes). Green, Ki-67; red, cyclin D1; yellow, co-localization of Ki-67 and cyclin D1. Red box, labial cervical loop region; yellow box, odontoblast region. Scale bars, $100 \mu \mathrm{m}$. 
E13
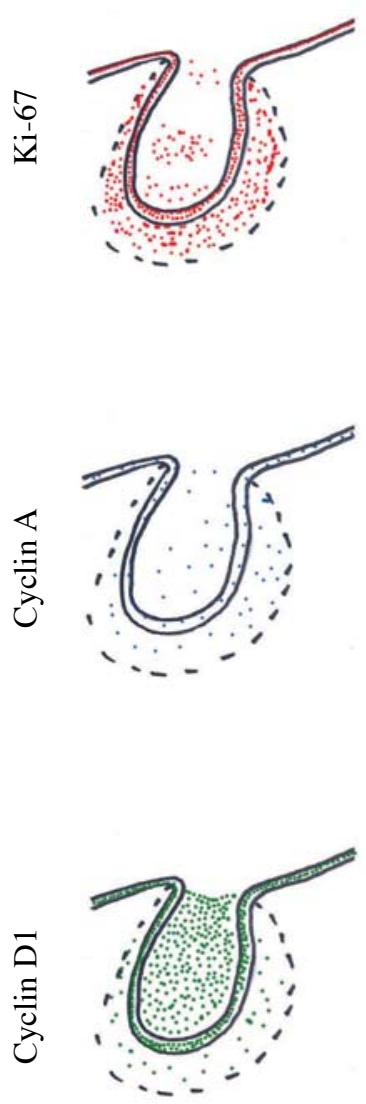

E14
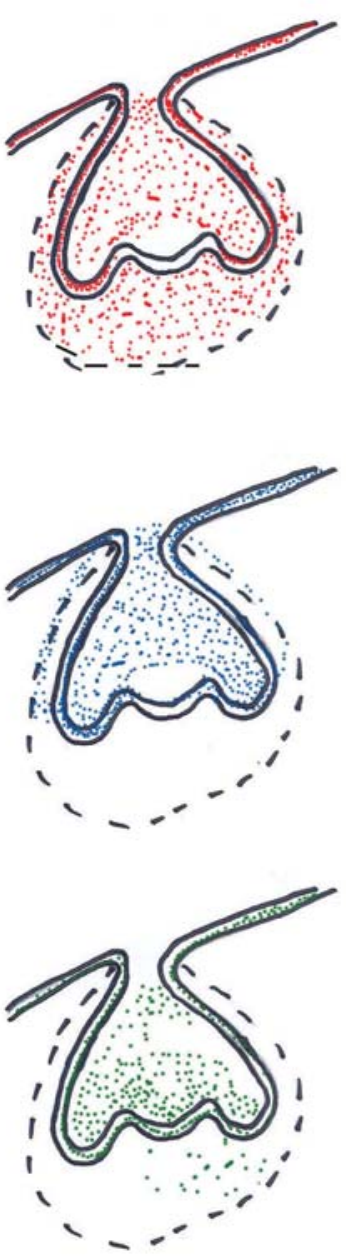

E16
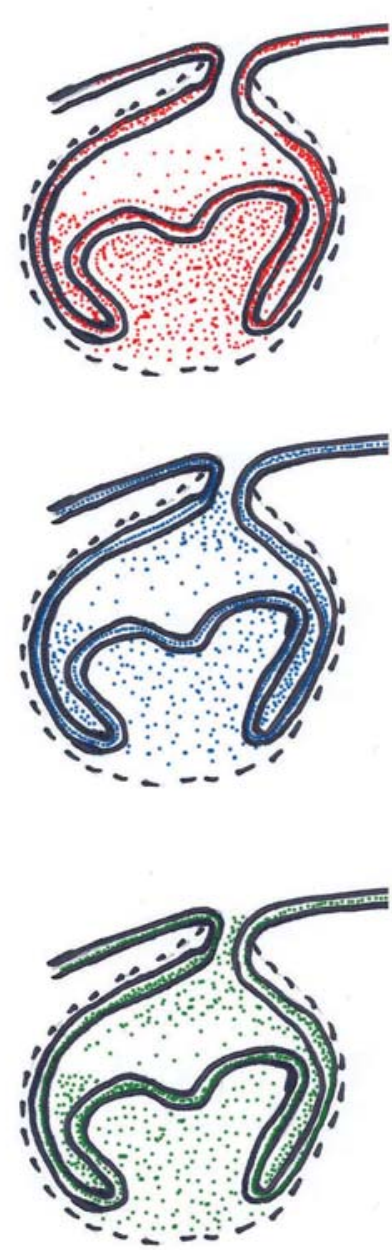

Fig. 4. Expression patterns of Ki-67, cyclin A, and cyclin D1 during molar development. At the bud stage (E13), Ki-67, cyclin A, and cyclin D1 detect proliferating cells in the molar tooth germ. At the cap stage (E14), Ki-67 and cyclin A detect proliferating cells located throughout the molar tooth germ except the primary enamel knot, whereas cyclin D1 detects not only proliferating cells but also cells within the primary enamel knot. At the bell stage (E16), Ki-67, cyclin A, and cyclin D1 detect proliferating cells in the molar tooth germ, whereas cyclin D1 also detects the non-basal cell layer dental lamina cells.

Since the expression patterns of Ki-67 and cyclin D1 showed some differences, we further compared the two by co-localizing them with immunofluorescence staining (Fig. 3 ). At the bud stage in the enamel organ, Ki-67 was localized broadly throughout the dental epithelium and the dental mesenchyme (Fig. 3A, G). On the other hand, cyclin D1 was mainly expressed in the dental epithelium on the apical side (Fig. 3D, G). Particularly, there was a cell group in the bulbous protrusion in the apical part of the enamel organ which expressed cyclin D1 but not Ki-67 (Fig. 3G, arrow). This pattern was similarly found at the cap stage when the enamel knot appeared (Fig. 3B, E, H). Ki-67 was absent while cyclin D1 was strongly expressed in the enam- el knot located in the apical side of the enamel organ between the labial and lingual cervical loops (Fig. 3H, arrow). At the bell stage, Ki-67 was expressed in the dental epithelium and the mesenchymal cells near the Ki-67-positive epithelium except the incisal tip region (Fig. 3C, I). Strong detection of cyclin D1 was found in the labial cervical loop, where it co-localized with Ki-67 (Fig. 3F, I, red boxes). Another strong localization of cyclin D1 was found in the middle and incisal regions of the tooth germ, where odontoblasts and mesenchymal cells adjacent to the odontoblasts expressed mainly cyclin D1 but not Ki-67 (Fig. 3F, I, yellow boxes). 
E13
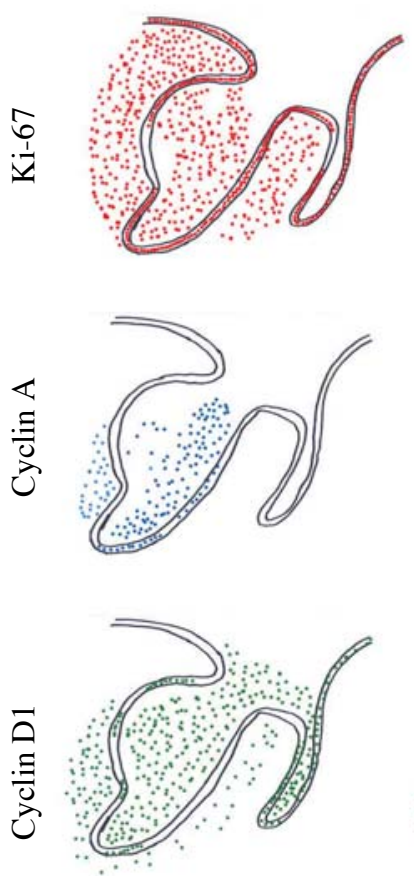

E14
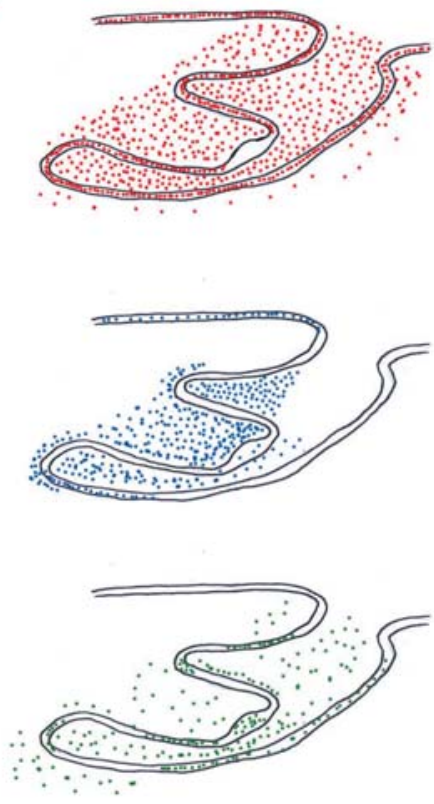

E16
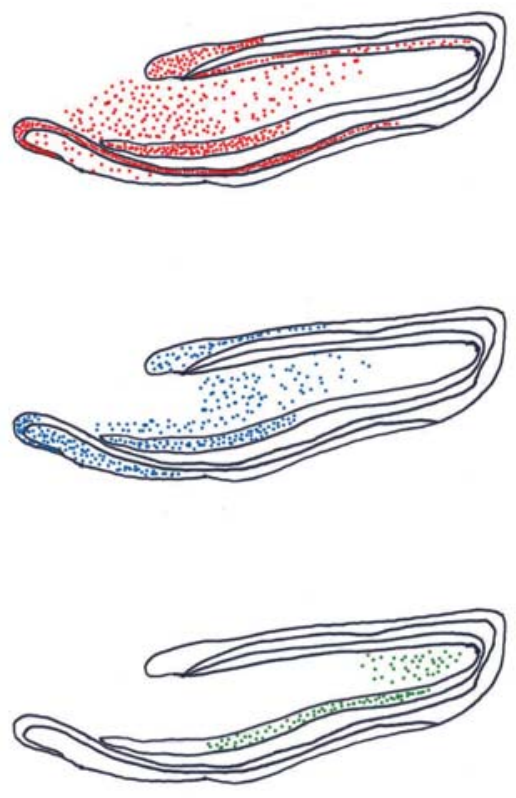

Fig. 5. Expression patterns of Ki-67, cyclin A, and cyclin D1 during incisor development. At the bud stage (E13) and the cap stage (E14), $\mathrm{Ki}-67$ and cyclin A detect proliferating cells in the incisor tooth germ, excluding cells in the apical protrusion (bud stage) and enamel knot cells (cap stage); whereas cyclin D1 detects the cells in the apical protrusion (bud stage) and enamel knot cells (cap stage). At the bell stage (E16), Ki-67 and cyclin A detect proliferating epithelial and mesenchymal cells in the apical part of the tooth germ; whereas cyclin D1 detects odontoblasts and adjacent dental papilla cells in the middle and incisal part of the tooth germ.

\section{Discussion}

In this study, we aimed to elucidate the characteristics of odontogenic cells that compose the tooth germ and understand how they play their parts during tooth development by focusing on cell proliferation, which is a key event during odontogenesis. Proliferating cells were well demonstrated by examining the expression patterns of Ki-67, which detects cells either in the G1, S, G2, or mitosis phase [13]. Ki-67-positive cells were present in the dental epithelium and mesenchyme at the bud, cap, and bell stages. We further dissected the cell cycle by comparatively analyzing the time-course changes in expression patterns of Ki-67, cyclin A, and cyclin D1. Cyclin A marked proliferating cells in the $S$ phase [16], and cyclin D1 detected cells transitioning from $\mathrm{G} 1$ to $\mathrm{S}$ phase [10]. Cyclin A was expressed in the $\mathrm{Ki}-67$-positive proliferating cells in the tooth germ, and its intensity was usually lower than that of Ki-67 in the developing molar and incisor tooth germs. Cyclin D1 was also expressed in the proliferating cells in the molar tooth germ at the bud stage to the bell stage, and its expression was stronger in the dental epithelium compared to the weak expression in the dental mesenchyme. Similar patterns were observed in the incisor tooth germ at the bud and cap stages. Reversely, at particular regions in the incisor tooth germ at the bell stage, cyclin D1 was weaker in the dental epithelium compared to the dental mesenchyme. In specific, odontoblasts in the dental papilla and adjacent mesenchymal cells exhibited high and specific expression of cyclin D1 compared to the nearby dental epithelium, where cyclin D1 expression was weak. In addition, Ki-67 was absent in these odontoblasts and adjacent mesenchymal cells, indicating that these cells were not undergoing cell proliferation.

The enamel knot, which was present at the cap stage and serving as a signaling molecule-secreting center, did not express Ki-67 or cyclin A, proving itself to be a nonproliferative cell cluster. The enamel knot is also known to express p21, a CDK inhibitor, in response to BMP-4 that is secreted from the dental mesenchyme [5]. p21 is 
known to inactivate the functions of CDK and cyclin A indirectly and eventually inhibit cell proliferation $[17,18]$. Therefore, p21 may be a candidate suppressor that regulates the expressions of Ki-67 and cyclin A. Interestingly, cyclin D1 was expressed in the enamel knot, where Ki-67 nor cyclin A was expressed, in the cap stage molar and incisor tooth germs. Similar patterns were also observed in the bud stage incisor enamel organ. A bulbous protrusion in the apical region of the enamel organ contained a Ki-67-negative, cyclin A-negative, and cyclin D1-positive region, suggesting that this region may become the enamel knot at the cap stage incisor tooth germ. These findings suggest that these cells are in the G0 phase since cyclin D1 has been reported to be expressed in G0 phase cells that were not proliferating [13]. In addition, the expression of p21 may be a sign that the enamel knot has exited from the G1 phase of the cell cycle to the G0 phase [5,19].

Our results provide information on the specific cell cycle phases in the developing mouse incisor and molar tooth germ for the first time. We also identified cells exhibiting a distinct expression pattern, where cyclin D1 was present but Ki-67 and cyclin A were absent, in the bell stage incisor odontoblast region and the cap stage enamel knot. These findings can be further related with previous studies that have been demonstrated in the incisor odontoblasts and the enamel knot. Furthermore, future studies investigating the network that lies among cell cycle and various signaling molecules and pathways would be necessary to reveal the complicated mechanisms that underlie tooth development.

\section{References}

1. Lesot H, Brook AH. Epithelial histogenesis during tooth development. Arch Oral Biol. 2009; 54 Suppl 1:S25-33.

2. Thesleff I, Nieminen P. Tooth morphogenesis and cell differentiation. Curr Opin Cell Biol. 1996; 8:844-50.

3. Jernvall J, Thesleff I. Tooth shape formation and tooth renewal: evolving with the same signals. Development. 2012; 139:3487-97.

4. Jernvall J, Kettunen P, Karavanova I, Martin LB, Thesleff I. Evidence for the role of the enamel knot as a control center in mammalian tooth cusp formation: non-dividing cells express growth stimulating Fgf-4 gene. Int J Dev Biol. 1994; 38:463-9.

5. Jernvall J, Aberg T, Kettunen P, Keränen S, Thesleff I. The life history of an embryonic signaling center: BMP-4 induces p21 and is associated with apoptosis in the mouse tooth enamel knot. Development. 1998; 125:161-9.

6. Salazar-Ciudad I. Tooth morphogenesis in vivo, in vitro, and in silico. Curr Top Dev Biol. 2008; 81:341-71.

7. Cooper GM. The Cell: A Molecular Approach, 2nd ed. Massachusetts: Sinauer Associates; 2000.

8. Galderisi U, Jori FP, Giordano A. Cell cycle regulation and neural differentiation. Oncogene. 2003; 22:5208-19.

9. Kumar V, Abbas AK, Fausto N. Robbins and Cotran Pathological Basis of Disease, 7th ed. Pennsylvania: Saunders; 2004.

10. Moore JD. In the wrong place at the wrong time: does cyclin mislocalization drive oncogenic transformation? Nat Rev Cancer. 2013; 13:201-8.

11. Henglein B, Chenivesse X, Wang J, Eick D, Bréchot C. Structure and cell cycle-regulated transcription of the human cyclin A gene. Proc Natl Acad Sci USA. 1994; 91:5490-4.

12. Yam CH, Fung TK, Poon RY. Cyclin A in cell cycle control and cancer. Cell Mol Life Sci. 2002; 59:1317-26.

13. Scholzen T, Gerdes J. The Ki-67 protein: from the known and the unknown. J Cell Physiol. 2000; 182:311-22.

14. Sugimoto M, Martin N, Wilks DP, Tamai K, Huot TJ, Pantoja $\mathrm{C}$, et al. Activation of cyclin D1-kinase in murine fibroblasts lacking both p21 (Cip1) and p27 (Kip1). Oncogene. 2002; 21:8067-74.

15. Catón J, Tucker AS. Current knowledge of tooth development: patterning and mineralization of the murine dentition. J Anat. 2009; 214:502-15.

16. Bendris N, Lemmers B, Blanchard JM, Arsic N. Cyclin A2 mutagenesis analysis: a new insight into $\mathrm{CDK}$ activation and cellular localization requirements. PLoS One. 2011; 6: e22879.

17. Levine AJ. p53, the cellular gatekeeper for growth and division. Cell. 1997; 88:323-31.

18. Soucek T, Pusch O, Hengstschläger-Ottnad E, Adams PD, Hengstschläger M. Deregulated expression of E2F-1 induces cyclin A- and E-associated kinase activities independently from cell cycle position. Oncogene. 1997; 14:22517.

19. Bloch-Zupan A, Leveillard T, Gorry P, Fausser JL, Ruch JV. Expression of p21 (WAF1/CIP1) during mouse odontogenesis. Eur J Oral Sci. 1998; 106 Suppl 1:S104-11. 


\title{
치아발생 과정 중에 Ki-67, 싸이클린 A, 싸이클린 D1의 발현양상
}

\author{
권혁제 ${ }^{\dagger}$, 윤경식, 정한성 ${ }^{\dagger}$ \\ 연세대학교 치과대학 구강생물학교실 해부 및 발생생물학
}

간추림 : 치아발생 및 형태형성 과정에서 치아상피와 치아간엽을 구성하는 세포는 동적인 세포주기의 변화가 일어난다. 현재까지 세포증식은 치아발생에 중요한 현상으로 알려져 있지만, 치아발생 중에 일어나는 복잡한 분 자적 기전과 연관해서 세포주기의 각 시기가 어떻게 관여하는지에 대해서는 충분한 연구가 이루어지지 않았다. 그러므로 본 연구는 치아발생 기전과 세포주기의 시기의 변화와의 관계를 밝히고자 하였다.

치아발생 과정에서 일어나는 형태변화를 확인하기 위해 싹시기, 모자시기, 종시기의 쥐 앞니 및 어금니 치배 를 헤마톡실린-에오신으로 염색하여 조직학적으로 관찰하였다. 또한 세포주기 시기의 표지자인 Ki-67, 싸이클린 $\mathrm{A}$, 싸이클린 D1의 발현양상을 관찰하기 위해 면역조직화학염색을 시행하였다. 싹시기, 모자시기, 종시기에서 증 식하는 세포들은 Ki-67과 싸이클린 A를 발현하는 것을 확인하였다. 싸이클린 D1은 앞니의 상아질모세포 및 모 자시기의 사기질결절에서 특이적인 발현을 보였으며, 이곳에서는 Ki-67이나 싸이클린 A가 발현되지 않는다는 것을 발견하였다.

본 연구는 치아발생 중 각 주요 시기에서 세포주기의 변화를 관찰하였으며, 이는 치아발생에 관여하는 기전 에 대한 중요한 정보를 제공한다. 또한 본 연구의 결과는 지금까지의 앞니의 사기질모세포 및 사기질결절의 특 성에 대한 지식을 이해하는 데에 중요한 자료가 될 것으로 사료된다.

찾아보기 낱말 : 세포주기, Ki-67, 싸이클린 A, 싸이클린 D1, 치아발생

$\dagger$ 공동 저자로 동등한 역할을 수행하였음. 교신저자 : 권혁제, 정한성 (연세대학교 치과대학 구강생물학교실 해부 및 발생생물학) 전자우편 : eddy8139@yuhs.ac, hsjung@yuhs.ac 